\title{
ENHANCING INNOVATION ROLES OF PESANTREN BUSINESS INCUBATOR IN PONDOK PESANTREN SUNAN DRAJAT Biyati Ahwarumi ${ }^{1}$ Tjiptohadi Sawarjuwono ${ }^{2}$
}

Candidate Doctoral of Syariah Economy, Airlangga University, Paciran Lamongan 62264, Indonesia ${ }^{1}$ Senior Lecturer of Graduate Program, Syariah Economy, Airlangga University, Surabaya 60292, Indonesia ${ }^{2}$

\begin{abstract}
Business Incubator is one of PPSD's (Pondok Pesantren Sunan Drajat) sub-units that supports their own economy independency. PPSD have existed as an important part of education, social and especially economic institution for Muslim community in East Java. Each year, Muslim intellectuals graduate from PPDS as Santri graduates, and mostly work, not only as religion teachers, but also as entrepreneurs, back in their hometown. The phenomenon of Santri Entrepreneurs appears to be the main inspiration for Business Incubator foundation. The researcher subsequently observes such phenomenon, also known as Santri anti-poverty agent, by using Action Research method as a base of observation for data collecting, analysis and synthesis process. The aim is to describe innovative methods of PPSD's Business Incubator in generating entrepreneurs along with pesantren ecosystem where this research was conducted. The research findings are the description of knowledge management and recommendation for developing entrepreneurship within incubator related to PPSD policy.
\end{abstract}

Keywords: Business Incubator; innovative entrepreneurship; Pesantren Sunan Drajat.

\section{Introduction}

As written in Nusantara history, long before Dutch colonialism in Indonesia, Pesantren took an important role on Indonesian social economy as not less important than religious mission by their leader or named Kyai. Pesantren is the origin of Indonesia's education and social economic institution, pioneered by Walisanga or nine famous first kyai especially in Java. One of well-known pesantren is Pondok Pesantren Sunan Drajat (PPSD), located in Paciran, North Coast of East Java. For more than 40 years, PPSD have been existing as an important part of education, social and economic institution, particularly for surrounding Muslim community. PPSD continuously graduates many intellectual Muslims, also known as graduate Santri. The interesting phenomenon is that most of these Santri graduates work not only as religion teachers, but also as entrepreneurs as well, and this already happened in natural random fact. These santri graduates are also known as anti-poverty agents in their neighborhoods. The research method is Participant Action Research (PAR) as a base of data collecting, analysis and synthesis for the enhancement of entrepreneurship from pesantren. The aim of this research is designing a system that could generate entrepreneurs in a dedicated organization for entrepreneurship as blended part of the whole ecosystem. This dedicated organization called Pesantren Business Incubator was established by Pesantren stakeholder. The starting point is the integration of religion, social, and economy science masteries as a holistic concept of Modern Pesantren that refers to the basic concept of personal independence in Islam. Business incubator stands as an independent and dedicated part of pesantren that runs all entrepreneurship activities from planning to evaluating stage.

The findings of this paper include: (1) Description of knowledge management for anti-poverty entrepreneur, (2) Design of pesantren business incubator management in knowledge, process, and enchantments, (3) Recommendation for stake holders in developing entrepreneurship in the incubator related to PPSD policy. Business incubator in pesantren is important, and somehow it needs to be enhanced. Later on in the global economic concept, it is believed that entrepreneurship will be deeply needed by a country like Indonesia. Entrepreneurship has a close relationship to business and economy strength to gain prosperity in a community (Dollinger, 2003). As a part of Indonesian community, pesantren develops its

\footnotetext{
1 ahwarumi@gmail.com

2 tjiptohadi@feb.unair.ac.id
} 
own sub-organization that generates entrepreneurs. Experts say that this organization is merely the same with the term Business Incubator. Provided with better approach and more systematic study, this research could become a reference for enhancing business incubator for other pesantrens.

\section{Literature Review}

There are some literatures reviews referred by researchers in order to find both theory and practical foundation to compose hypothesis, analysis, and conclusion. The roles of business incubator in PPSD in generating local Islamic entrepreneurs can be tracked from these literatures with historical content and analytical forecasting, especially in economic term. The literatures that can be categorized based on subject are: (1) Literature of Pondok Pesantren particularly Pesantren Sunan Drajat that consists of its history, values, and current existing type of Entrepreneurship, (2) Business Incubator in Pesantren (IBP) with 7S serving Scheme, (3) IBP management, (4) Islamic Entrepreneur References as Role Model, (5) Formulation of Pesantren - Islamic Entrepreneurship in PPSD incubator.

Pesantren inherits and maintains the continuity of Islamic tradition developed by ulama (kyai) from time to time. History records that Pesantren has existed for hundreds of years, reaching almost all levels of Indonesian Muslim society. Enduring to this day, even though it has existed for hundreds of years, long before Indonesian's independence, Pesantren still remains as a strengthening institution as well as institutional pattern method of social and cultural education and economy that boldly marked the history of Indonesian development. Early foundation of pesantren as boarding school in Indonesia was in 10th century AD (Sunyoto, 2015).

Some studies claim that "pesantren has been recognized as an educational institution that has participated in educating the nation". Today the contribution of pesantren to national development occupies a very important position (Rofiq, 2005: xii). The potential of pesantren is also high in the form of tangible and intangible aspects. The large number of pesantren human resources with uniformity of faith, ideology, and militancy has been acknowledged in history and declared as a great force supporting the spirit of this nation as well as the relentless non-stop resistance for the colonial. This potential still exists during this day. The large number of santri, santri adherence and distribution of pesantren that almost exist in every region especially Java island, frequently become the target of some politic and economical group to seek for support of time/ public.

In deeper review, literature of Pondok Pesantren particularly Pesantren Sunan Drajat (PPSD) provides a view point both of historical and recent of PPSD (Ahsan, 2015). Strength, Weakness, Opportunity, and Threat factor would be analysed in terms of PPSD status as Pondok Pesantren that puts economic factor as an important aspect. It is so important that PPSD has Economic Department that manages financial aspect of all PPSD business and operational units. One of PPSD Unit under Economic Department is Business Incubator that embedded within Economic Department organization.

Business Incubator (IB) in Pesantren (PBI) consists of 7S serving scheme. As many other incubator business in all over the world, PPSDs IB does nurturing process in order to give start-up or entrepreneur the ability to grow a sustainable living for their business in the Future. The 7S serving scheme are providing Space, Support, Shared facilities, Service, Skill development, Synergy, and Seed Capital.

PBI Operational runs under the management system of PPSD Economic Department with 9 (nine) major Components. These 9M managerial areas are: (1) Mission Statement, (2) Market, (3) Management, (4) Man Power, (5) Methods, (6) Machine, (7) Material, (8) Money, and (9) MIS (Management Information System). Islamic entrepreneur's reference for role model as Moslem always refers to Qur'an and Sunnah that is reflected in the figure of Prophet Muhammad SAW (Antonio, 2011). In the matter of entrepreneurship Prophet Muhammad SAW was always supported by his beloved wife, Khadijah, a wellknown and successful entrepreneur at that time. Formulation of Pesantren - Innovative and Islamic entrepreneurship in PPSD Incubator is now under progress as the researcher's ${ }^{1}$ subject of doctoral, dissertation, and hopefully in 2018 , it would be published after the discussion in doctoral forum.

\section{Methodology}

The chosen research methodology is Participant Action Research (PAR) that becomes the basis of knowledge collecting, analysis process, synthesis and resuming research. This PAR method is then simplified and modified by the researcher into system approach which is used as Action Research (AR). AR becomes one type of applied social research that essentially analyzes a social experiment by introducing a new policy and then takes a resume from actions of monitoring its effects (Bogdan et al, 2007; Hotler, 1993). In this case, innovative policy that generates Islamic entrepreneur is the main object of PPSD that 
would be analyzed and formulated by monitoring its effects. The reasons that encourage researchers to use this action research methods are:

a. Researchers and stakeholders can jointly identify problems, find causes of problems and intervene on issues that occur. So the problem was identified after a dialogue between researchers and related parties and achieved a common understanding (Hotler et all, 1993 p. 298).

b. The formation of mutual understanding between researchers and related parties will increase collective awareness, so it will be easier if there is a change on something related to systems or methods. For example, the system to foster the soul of entrepreneur's rahmatan lil alamin and the management of effective and optimal business.

c. Flexible principles in AR. Although AR is done with careful planning and implementation, researchers and stakeholders may be able to revise the plan if there is a sudden change of situation e.g. in growing the entrepreneur's spirit of santri thorugh another method.

Baseline action research, as revealed by Metler and Charles (2011): First, action research deals with the current problem, not other or someone else's problem. Second, action research is timely or immediate, action research can start now-or whenever considered ready-and deliver results that are immediate. Third, action research, as a process can also increase the fabric of stronger relationships among colleagues who become partners. Action Research (AR) conducted by the researcher can be described as diagram below:

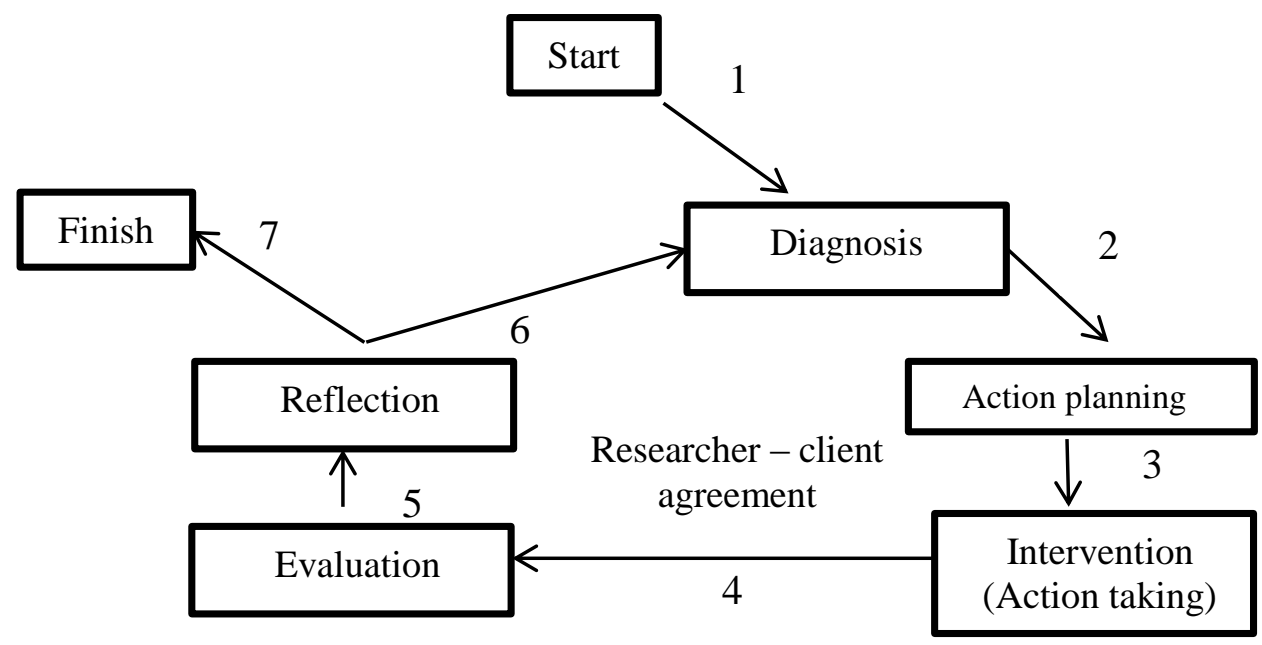

Figure 1

Research method - flowchart

Phrases undertaken in this study as described in flowchart above include the following steps:

1. Determining the problem formulation and research questions, namely: (1) how to grow Islamic entrepreneurs' rahmatan lil alamin soul? (2) How is the management of the pesantren business incubator to achieve maximum performance? (3) What is the potential power of business incubator synergy among pesantren and society?

2. Conducting literature and previous research review related to problem formulation

3. Conducting data collection by in-depth interviews, FGD (Focused Group Discussion), and documentation

4. Doing action planning and action taking

5. Evaluating all action taking

6. Reflecting / learning from this action research process

7. Compiling conclusions, suggestions, and research implications, so further researcher can develop better result.

\section{Discussion}

The discussion is preceded by the analysis on roles of business incubator's roles in Pondok Pesantren Sunan Drajat (PPSD), which has put many efforts in generating Santri entrepreneurs for four 
years. Based on the historical review, vision-mission, and literature of PPSD, potential resources and modern style of pesantren management have given some substances to be discussed in the context of this research.

Global background for this research can be described by examining the status of pesantren within nation current well-being. Indonesia needs further fostering stability, national economic independence, and equitable distribution of development amid the dynamic world economy. This growth can be done through structural economic changes by encouraging competitive, innovative, and dynamic private business sector, which one of them is through the growth of entrepreneurship (Bygrave, 1989; Bygrave et al, 2011). Entrepreneurship is proven to have strategic potential and role in some prosperous countries like Singapore, USA, China, through its great contribution to the improvement of social-economic values and the absorption of manpower created by its entrepreneurs. This entrepreneur can be born from various institutions, one of which the most popular is Business Incubator (Lumpkin, 1996; Lowe, 2006). The role of business incubator is as a sub-section of educational institutions or the like that provides widespread space for capacity building and mentoring activities in the context of mental formation as well as business models of entrepreneur candidates. Business incubator begin to develop in many countries. This is due to the important role of business incubator to generate entrepreneurs who are able to grow the community's economic level and well-being through their innovation. For example, Stal et al (2016) have researched the application of business incubator concept in Brazil. Many universities in Brazil are developing a new business creation with technologies transferring from university to society. They used university as an institution that generates the experts and transfers their knowledge to society, in this case is a company, in which they call it capitalization of knowledge and entrepreneurial university. It involves the relationship between university and non-academic partners. University is one of many educational institutions aimed to generate experts or transfer of ideas, for example knowledge and technology that contribute to the country (Chais et al, 2017). Not only university, but also there are other educational institution which can lead to business incubator forming.

Indonesian society with the majority of Muslim population, as recorded in history, had a strong educational institution so-called Pondok Pesantren, the original growing from the archipelago as well as a strength in the field of Islamic education, social, and national economy. Pesantren inherits and maintains the continuity of Islamic tradition has been developed by Ulama (kyai) from time to time. History records that Pesantren have existed for hundreds of years before Indonesia as Nation formed, reaching almost all levels of Muslim society. Enduring to this day, even though it has existed for hundreds of years long before Indonesian independence, formed and tested by the time of Pesantren as a strengthening institution as well as institutional pattern method of social and cultural education and economic boldly marked the history of Indonesia development. One of the existing Pondok Pesantren currently is Pondok Pesantren Sunan Drajat (PPSD) with Economy Department unit as the integrator of all economics and business activities, which attempt to leverage regional business well-being beside its need of economic independency. The founding of Economy Department is based on need for coordination and synergy of the economy and business units in PPSD. Major functions of the Economy Department is conducting economic governance for PPSD Business Units include: a) Product-Based, there are AMDK (bottled drinking water) of Aidrat brand, Mengkudu Juice, Kemiri Sunan, Kisda Fertilizer, Sunan Drajat Convection, Ocean Salt; b) Services-Based, there are PT. SDL (NPK FERTILIZER, Equipment Rental and Mining), Radio Persada, Persada TV, Sunan Drajat Printing, Laundry Sunan Drajat, Warnet Putra and Putri, Copy of Sunan Drajat, Cattle and Goat Farm, Chicken egg; c) Retail-Based, there are Sunan Drajat Stores, Sunan Drajat Book Store, Sunan Drajat Cafeteria. The vision of Economy Department in PPSD is to improve the management of Pesantren business potential in order to achieve professional performance maximally to build the welfare of Muslim civil society. The missions are (1) Establishing work function of pesantren business system effectively and efficiently, (2) Applying the business system light patterns that becomes enlighten to surrounding, (3) Developing and optimizing every business that has been running in PPSD, (4) Implementing the PPSD's SOP (Standard Operating Procedure) for all work execution activities, (5) Create a conducive working environment so that applied work culture in line with Islamic values. 
Within this Economy Department of PPSD, stands Business Incubator Unit that make Islamic entrepreneurship become top priority through implanting entrepreneurship soul to its Santri. Planting entrepreneur soul and independence spirit is what is applied PPSD, from the first time was established in 1975 until now 2017, it has 12,000 Santri and stands on 140 ha land (profile PPSD, 2016). PPSD becomes one of independent and low cost Pesantren, such as providing all Santri's need for accommodation and meals. From the number of students, 25\% of Santri get free scholarships covered by PPSD Foundation with land expansion, physical development, established, and managed several business units. PPSD's several business units are not only providing benefits that cover all operational cost, but also giving a chance for Santri internship that leads to Santri entrepreneurship, later on this scheme becomes the seed of Pesantren business incubator. The seeding process of students (santri) in term of nurturing all its needs factor to be an entrepreneur is the root of incubator concept, focusing on business aspect, then making the business incubator.

The main concept is the creation and implementation of host institution that prepares the prospective entrepreneurs by fostering the power of new entrepreneurs (tenant/ incubator member) to be independent. These tenants are selected start up consisting of group or individual that runs new business. Because of this mechanism, tenants are considered as superior seed for economic motor of business. As only Sunatullah that the superior seeds will survive and grow strong independently, if planted in a conducive, well-treated, and fertilized environment based on their needs (Arifin, 1993). The pattern of fertilization of entrepreneurial candidates through institutions that functions as foster parents has been used in many other countries, so the growth indicator of entrepreneur number is usually associated with the existing business incubator condition in that country. Business incubator takes part as a stimulator with a container nurturing or business fertilization that is expected to grow the business in community, then the subsequent impact is to create sustainable development (Hernandez et al, 2016).

According to the State Minister of Cooperatives and SMEs Indonesia no 81.3/ Kep/M.KUKM /VIII/2002, (a) Incubation is the process of fostering small businesses and / or new product development by business incubators in the provision of facilities and business infrastructure, business development and management and technology support; (b) Incubator is an institution engaged in the provision of facilities and business development, both management and technology for small and medium enterprises to improve and develop their business activities and / or development of new products in order to develop a tough entrepreneur and / or competitive new products within a certain period of time.

Business incubator plays a role to accelerate the growth of new entrepreneurs, and develop and strengthen the business that has been run by entrepreneurs, especially during difficult times in the early years of business (Scaramuzzi, 2002; Vedovello and Godinho, 2003; Setyobudi, 2012). The assist of incubator for tenants covers all preventing action of sudden or premature death of tenants business. The assistance can be in the form of a variety activities ranging from consulting management and business engineering, compiling business networks up to the service of office management facilities. Experience shows that less than $10 \%$ of tenants experience business failure at the incubator level. Data in the UK showed that $80 \%$ of companies undergoing business incubator process were more successful than only $33 \%$ who never underwent business incubator. It was evaluated at 5 years after the company escaped from business incubator (Setyobudi, 2012). The main purpose of Business Incubator is to produce an independent company especially in financial aspect. Companies that have successfully graduated from business incubators have a variety potentials such as employment creation, technology transferring, technology commercialization, economic resource devaluation, human resource revitalization, business capital investment, increased opportunities for women as business actors, and ending in empowerment of local and national economies. In many other studies, it is mentioned that the number of successful business incubator and graduated start-up is somehow related to nation competitiveness, development, and prosperity (Hernandez et al, 2016). Thus, the birth of new entrepreneurs and the occurrence of existing business development will make a real contribution to the national economy (Markatou, 2011; Strong, 2009; and Hamad, 2012). 
In global and regional study of incubator, the growth of business incubators in Indonesia is slowed down compared to the ASEAN regional countries. The number of business incubators in other countries is estimated at 3,500 and most of them are in America and Europe. There are 1,250 business incubators in America, 900 in Europe, 300 in the UK, and partly in ASEAN (BI, 2006). Here is the data of business incubator in some ASEAN countries. In Indonesia, the number of incubators in 2015 has increased to 81 incubators consisting of 35 incubators residing in state universities, 24 incubators located in private universities, 12 private sector incubator, 7 incubators in the government sector and 3 incubators in the public company (AIBI-Association of business incubator Indonesia, 2015).

In 2010, PPSD initialize the incubator system within its organization, but it still remains in the area of Pesantren values and supervision. Later, this incubator grows formally inside the economy department. Through its business incubator, PPSD has pioneered the growth of entrepreneurship with special character called "Entrepreneur Rahmatan lil 'alamin (ERA)". This ERA can become a new hope for the community, especially the Muslims to further improve the welfare of Ummah and reduce the social gap.

Entrepreneurs who are taught in PPSD are not only for their own interests, but they also are expected to become entrepreneurs with the character of rahmatan lil alamin, ie entrepreneurs who do not only think about material benefits (world of fortune), but also entrepreneurs based on the piety of God to continue to serve as God servant and as Khalifatullah. The spirit of gaining fortune in the Hereafter life is a manifestation of faith and believing in the last day. The terminology of rahmatal lil alamin comes from the word of God in Qur'an Surah an Anbiya: 107:

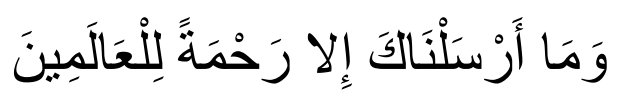

Meaning: And God (Allah) did not send you but gave mercy (as rahmatal lil alamin) to the universe (Qur'an Surah an Anbiya: 107 - Tafsir: Ministry of Religion republic Indonesia).

In the economic context, Rahmatan lil alamin can be interpreted as providing prosperity for the inhabitants of the universe. Welfare in Islam is defined as the fulfillment of the needs of addhoruriyah, which is called maqasid syariah (sharia purpose). So, in this case, the researcher puts maqoshid shari'ah as the basis of economic behavior in order to be able to realize the good deed in this world and the hereafter life. Imam al-Ghazali defines the Maqashid Shari'ah as follows:

\section{فرعاية المقاصد عبارة حاوية للابقاء ودفع القواطع والتحصيل على سبيل الابتداء}

Meaning: Safeguarding the intent and purpose of shari'ah is a fundamental effort to survive, resist the factors of destruction and encourage prosperity.

\section{هذه الشريعة ...وضعت لتحقيق مقاصد الشارع فى قيام مصالحهم فى الدين والدنيا معا}

Meaning: Verily, the Shari'ah is set aimed at the establishment of humanity in the world and the Hereafter life.

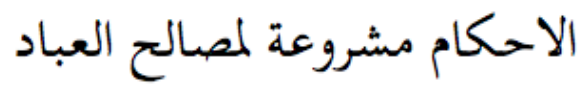

Meaning: Laws are enacted for the benefit of the servant (Zuhaily, 2011).

The concept of Rahmatan lil alamin - Islamic Entrepreneurship within Pesantren business incubator is the answer to challenge for the growth of the Muslim middle class, the rapid development of Muslim markets, and the changing behavior of Muslims. It is time to develop thinking about the world of business that benefits the world's prosperity. Basic concept of an entrepreneurial movement grows in line with the good nature and does not sharpen the gap of economic inequality. Yet, it distributes the natural 
wealth and human creativity to the whole of nature. A business activity that is more giving and responsible for the benefit of the people. Entrepreneur with the characteristics of rahmatan lil alamin (ERA) is very much in line with the values of PPSD, which are full devotion to God, independence in many ways, help, discipline and dare to take risks (Dhofier, 2015; Zubaedi, 2006; Zuhriy, 2011).

The entrepreneur with rahmatan lil alamin referred by PPSD is an entrepreneur who has strong leadership spirit, innovative, hard worker, have management knowledge, business processing technique, and good business development, with wide and visionary insight. But, his heart is subject to God, and is ready to take the role as Khalifatullah and Abdullah on earth. An entrepreneur who is ready to work hard lillahi taala, in every business process always applies the principles of sharia and the results of his work are not only for himself, but also for the benefits of Ummah. They are also ready to fight, fear no poverty for the people and being able to be a bright light for the environment, which is glowing because of God's light, and ready to serve for benefit the people (interview with PPSD Kyai, January 2017).

The role of business incubator in PPSD still needs to be improved based on the observation result and preliminary interview with PPSD economic leader (January 2017), from PPSD economic officer in period of 2017 as many as 250 people, fulfilling the standard of entrepreneur rahmatan lil alamin only 12 people or only $4,8 \%$, the fulfillment of business targets within the Pesantren is also not optimal yet (interview with CEO of PPSD economy). Considering the potential of SDI, PPSD potential of education, business, alumni, community, and social is big enough. It is important to do a research on how business incubator is able to grow entrepreneur rahmatan lil alamin optimally to support economic independence boarding school. This is the reason for the importance of research to be implemented.

Despite all shortages and obstacle here, the concept of PPSD Santri entrepreneurship within Pesantren Business Incubator (PBI) received a good response from the government of Indonesia as well as local authorities, universities, and several community institutions (Airlangga University, ITS, Ministry of Industry, KKP, Ministry of Religious Affairs, Ministry of National Education, Bank of Indonesia, BNI and others). Based from this support, PPSD compile some tasks to be done for development of its Business Incubator. Definition of Pesantren Business Incubator (PBI) for reference is not established yet/ direct example of ERA from previous studies, but researcher tend to describe Incubation as institution that owned and managed by pesantren to empower and optimize pesantren's potency in order to support self-reliance and to form Santri become entrepreneur rahmatan lil alamin (processed by researchers from several sources, 2017).

As the nature of other Business Incubator in the world, PPSD Business Incubator serves its tenant in term of services known as 7S. The "7S" Services are space, shared, services, support, skill development, seed capital, and synergy that implemented in PBI of PPSD, namely:

1. Space: PPSD incubator provides a place (places) for tenant/ start up entrepreneur to grow their business at an early stage, rooms / building in pesantren that function for operational (secretarial) and process of all incubation activities

2. Shared: PPSD incubator provides office facilities that can be used together, such as receptionists, conference rooms, telephone systems, computers, and security. IBP owns and provides facilities for shared tenant (general: office facilities Special: facilities according to the competence of tenants, for example: workshop, kitchen, packaging machine, etc.)

3. Service: PBI give complete services include management consulting and market issues, financial and legal aspects, and trade and technology information. IBP serve tenants in form of management consulting, information services, marketing, legal intermediation, technological enhancement, and certification facilitation.

4. Support: incubator provides support for access to research, professional, technological, international and investment networks. Pesantren function as a hub - liaison - lane for tenants gets access to information, business networks, tech support, etc.

5. Skill development: Skills development can be done through the practice of preparing business plans, management and other capabilities. IBP facilitates capacity building activities for tenants (training, workshops, internships, licenses, co-working, etc.)

6. Seed capital: Initial funding; can be done through internal rolling funds or by helping small business access to funding sources or existing financial institutions. IBP becomes part of the finance tenant solution, which may be network access with financial institutions, information on funding opportunities, or as a recommendation to other institutions that have financial solutions. Etc.)

7. Synergy: Tenant cooperation or competition between tenants and networks with universities, professionals and the international community. IBP facilitates cooperation and competition between tenant and other synergy schemes with broader networks (research institutions, professional business communities, colleges, etc.) 
In process of operating business incubator, Pesantren Management has 9M components, namely:

1) Mission Statement: formulating strategic plan (vision, mission, objectives, and operational plan) IBP refers to the character and vision of pesantren mission.

2) Market target: exploiting and expanding market already owned by pesantren internally and also external and its development potential modern-based Islamic management from and for santri.

3) Management: modern-based Islamic management from and for santri.

4) Man Power: optimizing all human resources involved in PBI operations.

5) Methods: practicing the principles of sharia in every incubation activity.

6) Machine: maximizing the utilization and maintenance of pesantren facilities and infrastructure as a facility of competency development and tenant business.

7) Material: prioritizing the use of best quality and local based resource pesantren.

8) Money: access, information, Islamic financial scheme (BMT, application of sharia contract).

9) Management Information System: utilizing database technology and IT based for competency development of Santri, pesantren business unit and business of tenant.

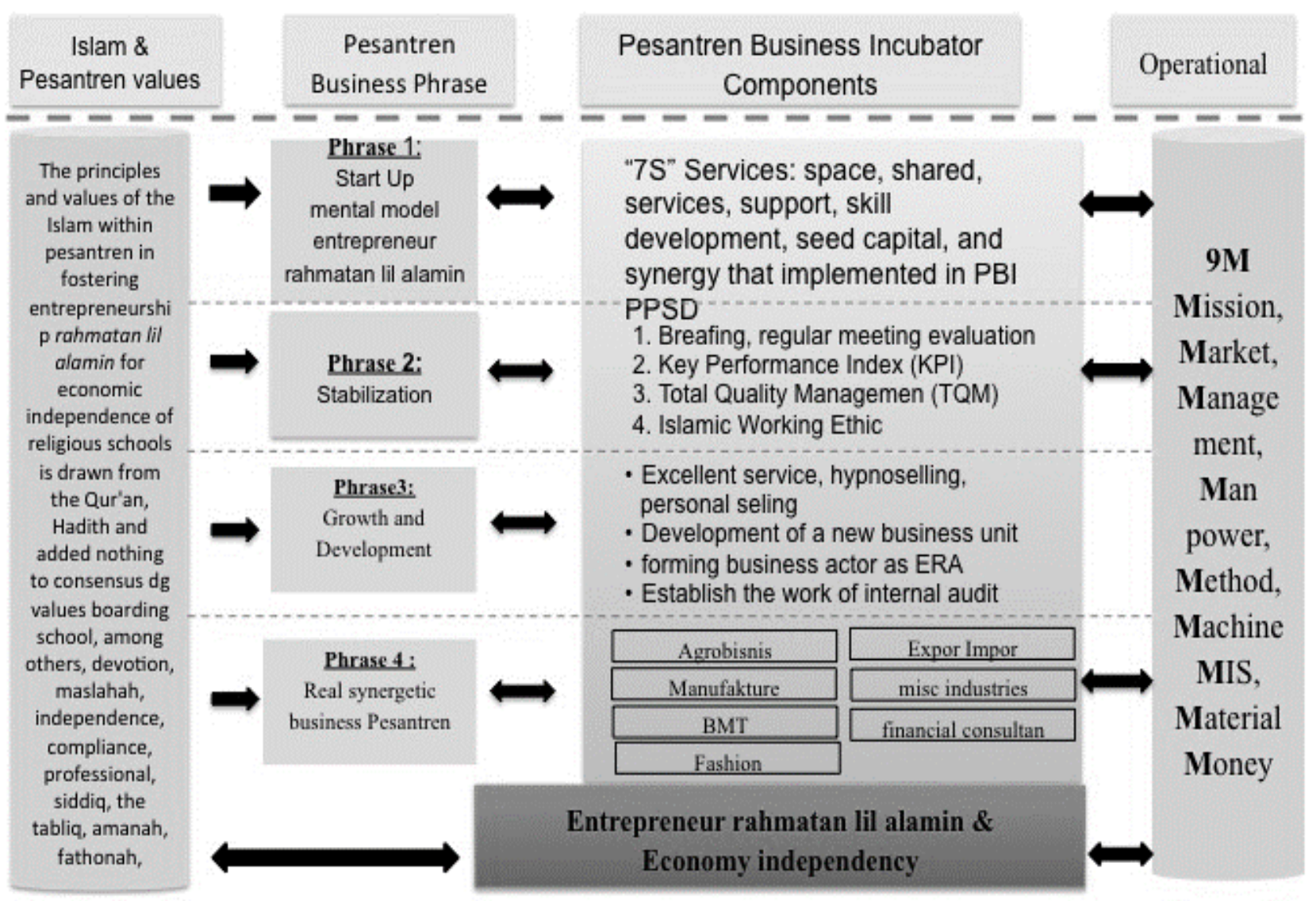

Figure 2. Innovation design of Pesantren Business Incubator

The component of "9M Management and 7S Services" from Pesantren Business Incubator (PBI) can be listed as follows:

- PBI Institution: (1) Strategic and operational plan, (2) Institution, (3) organization, (4) management (5) governance, (6) work program, (7) sustainability program

- Tenant of Pesantren Incubator Business: (1) Selected students, (2) alumni, (3) Tenant selected from other community groups (SAP - Santri Alumni People concept)

- Method: in wall (stay and running business in Pesantren), out wall (stay and running business outside Pesantren), online / e-incubator

- PBI operational infrastructure facilities: rooms in pesantren, pesantren business units, tools, machinery, modules, teaching materials etc. 
- Ecosystem (explains the network, its role, its position and its effect on the related components). The four main elements of IBP ecosystem are: Authorities, AN-NASL \& AN-NAFS (Community), AL MAAL (Business), AL- DIN \& AL-AQL (Research and Education), these elements must be present and have mutual linkage in order to make conducive ecosystem for entrepreneur growth.

The component of "9M Management and 7S Services" from Pesantren Business Incubator designed to assist the forming of Islamic rahmatan lil alamin entrepreneur is not only for generating the quantity of new business and economy power, but it also hopefully would form modern Islamic life style and work culture.

The modern Islamic work culture and life style means to actualize the full potential of our faith, modern information and technology, thought and remembrance and our values of scholarship to give the happiness to the universe. The essence and source of Islamic work culture is Al-Quran and As-Sunnah Rasulullah $S A W$. So the working culture of Islam is the process of becoming and encouraging creativity and innovation based on the ultimate truth-values. As the Word of Allah SWT:

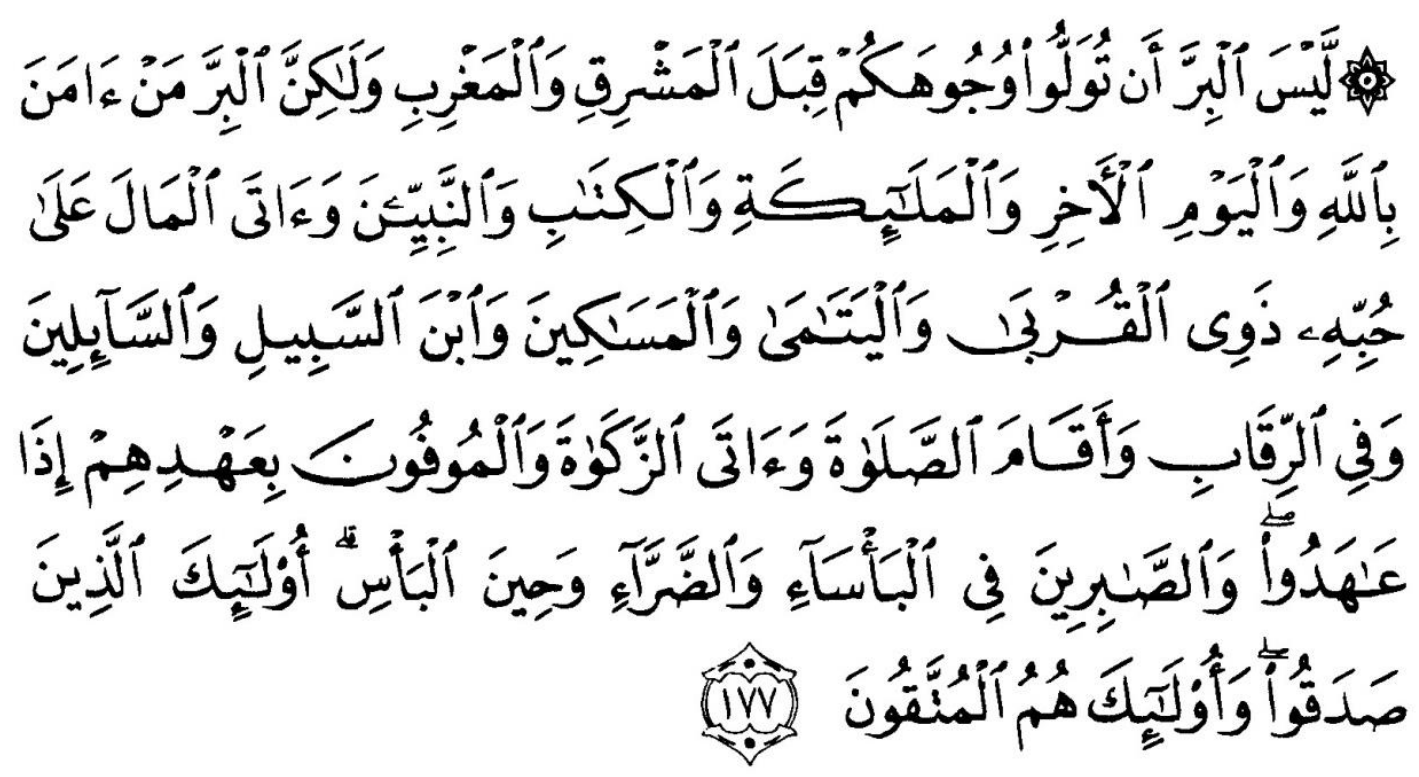

Meaning: "It is not your face to the east and the west a virtue, but Truly the virtue is to believe in God, the Last Day, the angels, the holly books, the prophets and give his beloved treasures to his relatives, orphans, the poor, the travelers (who need help) and the beggars; and (liberating) the servant of slaves, establishing the prayer, and performing the charity; and those who keep his promise when he promises, and those who are patient in narrow, suffering and in war. Those are the righteous (their faith); and they are those who fear Allah", (QS Al Baqarah: 177).

\section{Result}

The aim of this research is providing significant contribution in terms of academic manuscript that would become useful document for public, especially for Pesantren needs to relate their vision of economic sustainability and independency with entrepreneurship. The benefit of this document would:

- Become the reference material for pesantren to improve the performance of management of pesantren business incubator.

- Being a consideration materials for the leadership of pesantren in managing economic potential and developing business with Islamic entrepreneur (Entrepreneur Rahmatan lil Alamin- ERA) as value chain and sharia economy network booster.

- To be a research material development tools especially related to the growth of ERA and business incubator of pesantren for academic community with the hope to be more refined in the future.

- The expected outcome is an increase in the number of ERA in Pondok Pesantren Sunan Drajat.

- Entrepreneurship program in PPSD Business Incubator prove that economy of pesantren can be scaled 
up not only by conventional economic ways but also by innovative Entrepreneurship method.

\section{Conclusions, Limitations and Suggestions}

These are the summaries of the three components, namely: conclusions, suggestions and contributions of the research that can be listed as below:

1. Limitation area of research coverage is only on PPSD Paciran Lamongan North Coast of East Java, Indonesia where the Pesantren Business Incubator lies under Economy Department. Other pesantren Incubator Business or Pesantren itself has their own charateristic and uniqueness that might not fully suitable with the result of this research.

2. Conclusion:

a. Pondok Pesantren is one of suitable institutions to develop incubator for generating entrepreneurship in Indonesia to grow Islamic entrepreneurship that has Rahmatan lil Alamin, both as their uniqueness and strong character.

b. The role of PPSD, especially economic department is very potential to create Islamic entrepreneur and can give an example of innovative role of Pesantren for generating entrepreneurship.

c. The innovative role of PPSD that has been done to develop so far for Islamic entrepreneurship is tenant recruitment, mentoring, character building, cooperate working program and broaden networking.

d. Pesantren Business Incubator (BPI) is a pilot project of educational \& social organization that contribute to global economic values by generating Islamic Entrepreneur or ERA.

e. The innovative role of PPSD to be undertaken to further develop Islamic entrepreneurship are:

- Implementing PBI operations by maximizing the potential of 9M pesantren.

- Having a strategic plan, operational and sustainability programs that align and strengthen the values of the main Pesantren.

- Having the potential to develop and expand the principle of $7 \mathrm{~S}$ services to the maximum.

- Having big potential business optimization program based on local content and resources.

- Having a positive economic \& social effect to the environment around the boarding school with SDI recruitment priority from SAM scheme.

- Producing alumni and business networks that strengthen the economic independence of Indonesia, especially in the field of global economy.

3. Sugesstion from researcher for the upcoming similar topic or subject of innovation and entrepreneur are:

- Wider range of research area limitation would provide bigger ammount of contribution for entrepreneurship studies in Indonesia,

- Innovation must be defined in many alternative ways to bring better result and actions such as innovation in policy, management, product

- Entrepeneurship must be considered as a real competitive factor for a Nation not only as trending subject but also updated issues.

\section{References}

Ahsan, Muhammad. (2015). Peran Kepemimpinan Wirausaha Kyai Abdul Ghofur dalam Semangat Wirausaha (Studi Etnografi di Pesantren Sunan Drajat Lamongan Jawa Timur). Disertasi Program Studi Pascasarjana Fakultas Ekonomi dan Bisnis Universitas Brawijaya, Malang.

Arifin, Muhammad. (1993). Ilmu Pendidikan Islam. Jakarta: Bumi Aksara.

Al-Quran and Translation. (1992). Departemen Agama RI, Jakarta. Semarang: PT. Tunas Inti.

Antonio, M.S. (2011). Bisnis dan Entrepreneurship: Ensiklopedia Leadership dan Manajemen Muhammad saw. "The Super Leader Super Manager”. Jakarta Selatan: Tazkia Publishing.

Bogdan, R.C., and Biklen SK. (2007). Qualitative Research for Education: An Introduction to Theory and Methods. 5th ed. Boston: Allyn \& Bacon.

Bygrave, W. D. (1989). The Entrepreneurship Paradigm (I): A Philosophical Look at Its Research Methodologies, Entrepreneurship Theory and Practice, Vol. 14, No. 1, pp. 7 - 26.

Bygrave, W. and Zacharakis, A. (2011). Entrepreneurship. Second Edition. USA: John Wiley\&Sons Inc. 
Chais, C., Ganzer, P. P., \& Olea, P. M. (2017). Technology transfer between universities and companies: two cases of Brazilian universities. RAI Revista de Administração E Inovação. https://doi.org/10.1016/j.rai.2017.07.003.

Chirzin, M. Habib. (1995). Agama dan Ilmu dalam Pesantren (dalam Pesantren dan Pembaharuan), Jakarta: PT. Pustaka LP3ES.

Culley, R.M., and Hughey, J. (2008). Power and Public Participation in a Hazardous Waste Dispute: A Community Case Study. Springe Science + Business Media. December, pg. 99 - 114.

Dollinger, M.J. (2003). Entrepreneurship Strategies and Resources, International Edition, Third Edition. Prentice Hall, New Jersey.

Dhofier, Zamankhsyari. (2015). Tradisi Pesantren: Studi Pandangan Hidup Kyai dan Visinya mengenai masa depan Indonesia. Jakarta: LP3ES.

Hamad, E. (2012). The role of business incubators on innovation in SMEs. The conference of Small \& Medium Entreprises (BI). Alsharjah.

Hernández, R., \& Carrà, G. (2016). A Conceptual Approach for Business Incubator Interdependencies and Sustainable Development. Agriculture and Agricultural Science Procedia. https://doi.org/10.1016/j.aaspro.2016.02.054.

Hotler, et all. (1993). Action Research : What is it? How has it been used and how can it be used in nursing? Journal of Advanced Nursing 1993: 128; 298-304.

Lumpkin, G T; Dess, G.G. (1996). Clarifying the Entrepreneurial Orientation Construct and Linking It to Performance, The Academy of Management Review, Vol. 21, No. 1, pp. 135-172.

Lowe, R. and Marriott, S. (2006). Enterprise: Entrepreneurship And Innovation, Concept, Context And Commercialization, Elsevier, Burlington-USA.

Markatou, M. (2011). Entrepreneurship and innovation in Greece: do small and medium entrepresis innovate?, in Robert Gordon University, Ed 2011. Proceeding of $6^{\text {th }}$ European Conference on Innovation and Entrepreneurship, Aberdeen, 15-16 September, Academic Publishing Limited, Reading, pp. 621-628.

Nandram, S. and Samson, K. (2006). The Spirit of Entrepreneurship : Exploring The Essence of Entrepreneurship Through Personal Stories, Springer, Germany.

Rofiq A. (2005). Pemberdayaan Pesantren, Menuju Kemandirian dan Profesionalisme Santri dengan Metode Daurah Kebudayaan. Yogyakarta : PT. LKiS Pelangi Aksara.

Scaramuzzi, E. (2002). Incubator in Developing Countries: Status and Develoment Perspective. Info Dev Program. The World Bank Washington, DC.

Setyobudi. (2012). Inkubator Bisnis di Perguruan Tinggi. Makalah. Universitas Brawijaya.

Stal, E., Andreassi, T., \& Fujino, A. (2016). The role of university incubators in stimulating academic entrepreneurship. RAI Revista de Administração E Inovação. https://doi.org/10.1016/j.rai.2016.01.004.

Strong, M. (2009). Be the Solution: How Entrepreneurs and Conscious Capitalists Can Solve All the World's Problems. John Wiley \& Sons Inc., Hoboken New Jersey.

Sunyoto, Agus. (2012). Atlas Walisongo. Jakarta: Iiman Real.

Neergaard, H. and Ulhoi, JP. (ed.). (2007). Handbook Of Qualitative Research Methods In Entrepreneurship: Ethnographic Methods In Entrepreneurship Research (Bruce A. Johnstone). Edward Elgar Publishing, UK.

Vedovello, C. and Godinho, M. (2003). Bussiness incubators as a technological infrastructure for supporting small innovative firms activities. Int Journal Entrepreneurship and innovation Management, Vol 3 No1/2 pp 4-21.

Zubaedi. (2006). Pemberdayaan Masyarakat Berbasis Pesantren : Kontribusi Fiqh Sosial Kiai Sahal Mahfudz dalam Perubahan Nilai-Nilai Pesantren. Yogyakarta : Pustaka Pelajar.

Zuhriy, M Syaifuddien. (2011). Budaya Pesantren dan Pendidikan Karakter pada Pondok Pesantren Salaf. Jurnal Walisongo, Volume 19 Nomor 2. 
